\title{
Gender equality for women involvement in urban environmental preservation
}

\author{
Donna Asteria ${ }^{1 *}$, Habibullah Adi Negoro ${ }^{2}$ and Muhamad Rijal Soedrajad ${ }^{3}$ \\ ${ }^{1}$ Department of Communication, Faculty of Social and Political Science, Universitas \\ Indonesia, Depok, West Java 16424, Indonesia \\ ${ }^{2}$ Faculty of Economic and Business, Universitas Indonesia, Depok, West Java 16424, Indonesia \\ ${ }^{3}$ Department Philosophy, Faculty of Humanitiesm Universitas Indonesia, Depok, West Java 16424, \\ Indonesia
}

\begin{abstract}
The purpose of this study explores the relationship between environmental preservation and gender equality. Efforts to overcome the impacts of climate change in cities through environmental preservation must be carried out by all communities' participation. Gender equality very important to strengthen providing access to women to preservation activity in the urban environmental management. This study was conducted qualitatively with a literature review using a qualitative systematic review. The findings show that there are still obstacles to achieving gender equality in preserving the environment physically and non-physically. The gender aspect need to be elaborate the preservation activity with emphasis in human aspect to prevent environmental damages. Because women's way and their consistency contribution in environmental preservation shows that a gender equality approach is very important in environmental conservation activities to achieve urban area sustainable. To conclude, there is important relationship regarding environmental preservation with aspects of gender equality, regarding access and forms of involvement in activities. This study contributes to urban planning with a gender responsive approach, with a focus on involving women in urban preservation by reducing gender discrimination.
\end{abstract}

\section{Introduction}

Environmental preservation has earned attention for recent years since the global warming issues announced one decade ago [1]. Environmental protection with preservation as an effort to prevent and protect harmful impacts that cause environmental damage due to human activities in development urban areas. A gender responsive approach is currently needed to pay attention to the voices of women and men as participants and leaders in conducting conservation to increase resource productivity and promote more sustainable ecosystem management. Women and men play different roles in managing and use their natural environments in different ways. Effort for women involve in environmental management decision-making and leadership roles with use gender responsive approach as value to

\footnotetext{
*Corresponding author: donna@ui.ac.id
} 
improving gender equality. This is the key factors to achieve environmental sustainability. A study on the important role of women in environmental management, is found in Begum (2004) that women have a major contribution to development, both growth and management. Women have an important role in agriculture as well as for the survival of many people in marginalized communities [2]. Likewise, in Mirzaei et al (2009) in their research on the socio-cultural role of women in improving environmental quality, women are considered as the main factor in the transmission of the cultural and educational environment for future generations [3].

Environmental preservation efforts in cities with built environment conditions and limited natural sources are very important to reduce global warming effect. In nowadays various environmental issues such as environmental warming, air pollution, water, and accumulated waste have become situations that cannot be avoided by many city residents in their daily lives. In fact, environmental changes such as increasing average temperatures and highintensity heat waves will have an impact on health, social, and the economy of the global community [4]. From the past, city was a place that kept the attraction for many people to work and live in it. Many of them assume that there will be more complete facilities than the place of origin, the end of employment in the place of origin, the decline in production in the place of origin, to the perception of the ease of economic activities, making many people keep coming to the city. Urban locations are more susceptible to the effects of environmental change, increasing heat in particular, because of the effects exacerbated from the activities and facilities that affect each other in urban areas. The urbanization can provide greater opportunities for sustainable development but urbanization will also have an impact on the realization of the dream of sustainable development [5]. If population density is not accompanied by sufficient insight to protect the environment, the destruction of ecosystems and the environment might be a disaster.

The good ecosystem is one aspect that contributes to human well-being [6]. With a healthy environment, we can feel the cool air in the morning without worrying about air pollution. When we demand, need, or use, either actively or passively towards ecosystem and environmental components, our activities tend to depend on the usefulness of the environment and ecosystem [7]. Along with the advancement of technological development, the level of awareness to keep the environment clean and comfortable to live in should not be a difficult matter. Many experts have routinely worked to develop a framework of relations between humans and the environment so that environmental problems can be avoided [8]. By knowing the relationship of the environment, ecosystems, and human needs, the usefulness of ecosystems and the environment certainly involves evaluating the relationship between human actions and nature, as well as what we value in nature [9]. The environmental protection must be priority in urban developing.

Urbanization in the current global era is quite closely related to industrialization. Unfortunately, Shiva (1980) explains that technological advances aimed at human prosperity are feared to threaten nature, species of living things, including all humans [10]. With these various aspects, we might be expected to consider every development and activity so that diversity and environmental wealth are not destroyed because development without the power to support life is a threat. The epistemology brought by Shiva later became part of an effort to raise awareness of the human environment as eco-feminism. Actually, ecofeminism is an effort to raise awareness for all people outside of their gender identity in order to help maintain the environment well. However, some facts show that those who contribute more to nature conservation are people with feminine characters, in this case, women. Conversely, if the principle of masculinity dominates nature, we might assume that suppression of nature will increase. The study of women's groups in the context of the philosophy of eco-feminism shows the contribution of ideas on how to create a healthy natural environment. The gender 
aspect is an important element because the perspectives of men and women can produce different results findings [11].

In the time of the progress of the global economy which gave birth to many multinational companies as the women's participation in environmental preservation since the feminism raising [12]. This involvement start shortly after gender equality has just begun to rise, where women now have equal position and chance like men. Equality will have an impact on women's willingness and ability to be involved in social activities, including environmental conservation activities. In the United States, middle class women are indispensable in every struggle for environmental preservation in the United States. At that time, women became environmental activists and supporters of environmental reforms to stop pollution, conserve natural resources and conserve wild places and creatures [13]. The purpose of this study explores the relationship between environmental preservation and gender equality. This study contributes to urban planning with a gender responsive approach, with a focus on involving women in urban preservation by reducing gender discrimination.

\subsection{Linkage environmental preservation activities and the involvement of women}

The study of environmental preservation rarely relates the human aspect as the agent of the actor. Elaboration by linking gender aspects with the social and cultural contexts of society is a novelty in this study. Studies on environmental preservation prioritize studies from an ecological perspective and environmental protection from a technical aspect. Basically, environmental preservation can be classified to several categories, based on its core activities. Those are physical, and nonphysical activities. These activities have the same goal - to preserve the environments. These methods of environmental preservation have differences on the approach, subjects, and the key factors in the activities. Since these methods has differences in terms of subjects, approaches and the key factors, it may also have gender disparities [14].

The term of physical environmental preservation refers to the efforts, activities, and actions to help preserve the environment directly with our hands and physical presence. The physical activities can be formed in various ways. As the example, an individual or a group of people cleaning the wastes or neighbourhood is one of the physical activities. Another example is the recycling wastes itself, planting trees, and rubbish filtering by an individual or a group of people. The physical activities mean direct actions and approach to handle environmental problems. Since the physical activities often need high energy and intense physical participation, women have small contributions in this kind of physical activities. Moreover, their participation gets smaller in patriarch society, in which women are undesirable to handle hard physical activities. As the example, in many patriarch societies, women don't need to carry a sack of garbage, or clean large area of wasteland. This kind of paradigm has strong correlation with women's physical discrimination - men are assumed stronger than women. Since women are assumed have less physical energy than man, in these activity women are often do light physical activities such are cleaning dusts, help waste filtering or even help prepare snacks for men [15].

Nonphysical activities consist of several subtypes of activities such are campaign activities, diplomatic, and advertising activities. Campaign activities refer to attempts or efforts in which convince other people to become environmentally aware of their own wellbeing. The objective of this activity is to help increase the awareness of a phenomenon, especially environmental preservation [16]. Campaign activities has been spreading nowadays thanks to social media. This kind of campaign would help increase people's awareness to be involved on environmental preservation. As the example case, the announcement or attempt to reduce straws and plastics among people considered one of the 
environmental campaign activities. The other example of the campaign activities is the announcement for people to bring their own shopping bags and tumbler to reduce the onetime only plastic bags and bottles. These kinds of campaigns have grown more in recent decades than the previous decades, as the people's awareness of plastic danger has increased. Campaign activities does not have a gender discrimination since it does not have a big physical effort to be done. Hence in this kind of activity, the proportion of women's participation is higher than the physical activities. This campaign activities could be done by everyone, regardless their genders, even their physical ability. The main factors are used in this approach is the power of words, and people engagement [17]. Since the physical ability does not play important role in this activity, the campaign is more preferred to be one of the place women can take part on preservation activities. Campaign activities also does not have gender discrimination, yet in patriarch communities. In patriarch communities, still those environmental campaigns are done by men rather than women, although the proportion intensity (of women participation) is smaller than the physical activities. The next kind of nonphysical contribution is diplomatic activities. Diplomatic activities are not limited to advocacy, political attempts, and being people's representative. Diplomatic activities refer to the women's activity on diplomate the environmental preservation interest to the representatives. Being a project leader, representative or advocator for the sake of environment is the most frequent women contribution in the preservation, relatively compared to the men and physical activities [18].

This showed that relation between gender equality and environmental management about the same opportunities for women and men in preservation activities. Because gender equality provides opportunities for all people to have the same opportunity, especially for women who are included in marginalized groups. The existence of access and control over natural resources in urban areas will be able to support equal involvement and achieve prosperity for all communities. Women must have equal access to be involved in environmental management activities, especially preservation, include physical and nonphysical activities to prevent environmental damage.

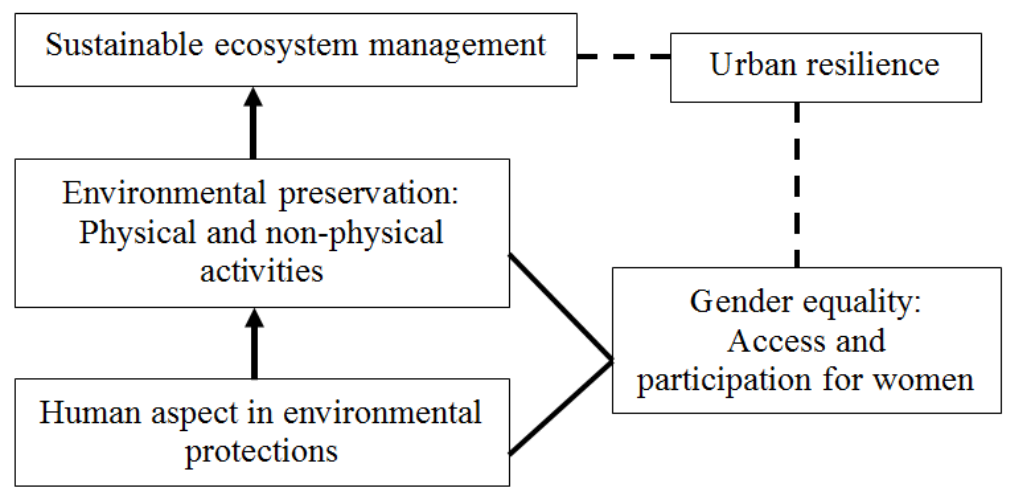

(Source: Synthesis result of literature review (private document), 2020)

Fig. 1. Conceptual framework

In Figure 1, related to the focus of the study on the relationship between environmental preservation and gender equality, conceptually it appears that the human aspect as environmental preservation actor is an important factor for the sustainability of environmental management. In the human aspect, all communities, including marginalized groups, must be able to access and be involved in environmental preservation activities in order to achieve urban resilience. This conceptual framework shows that the gender aspect, 
(with a focus on gender equality) is important in achieving sustainable environmental management, which is a form of environmental protection through preservation activities.

\section{Method}

This paper used qualitative approach with type conceptual paper compiled from literature review method. The method used qualitative systematic review [19] and the review is carried out based on secondary data. The emphasis analyses various articles related to environmental preservation and gender equality.

Literature study conducted on journal articles, dissertations, conference proceedings, and other documents relating to keywords. This review based on more than 25 literature by purposively where the literature in accordance with the keywords examined with the method written in the study includes conceptual exposure related to environmental preservation, gender equality, women and environmental activity, with references since 2000-2020. The review technique that is carried out consists of stages, namely: selecting according to the specified criteria with research question, and deciding the suitability and relevance of the problem, then linking all the studies between all material obtained, interpreting, then synthesizing the findings, and developing a synthesis to answer the problem as part of the elaboration carried out. This paper used qualitative approach with type conceptual paper compiled from literature review method [20]. The stages of the review process can be seen in Figure 2.

\begin{tabular}{|c|c|}
\hline $\begin{array}{c}\text { Step 1: } \\
\text { Prepare for the review by identification research } \\
\text { questions and examining review procedures }\end{array}$ & \multirow{3}{*}{$\begin{array}{l}\text { Data extract and data } \\
\text { synthesis (Reference selection } \\
\text { and exclusion of references): } \\
\text { - by removing references that are } \\
\text { duplicate/the same } \\
\text { - the contents of the article do } \\
\text { not match the focus of the } \\
\text { problem } \\
\text { - the references are not published } \\
\text { full texts } \\
\text { - the review is conducted from } \\
\text { qualitative content, not } \\
\text { quantitative references }\end{array}$} \\
\hline $\begin{array}{l}\text { Step 2: } \\
\text { The stages of conducting a review: searching for } \\
\text { sources on google scholar and selecting references } \\
\text { with the keywords urban environmental } \\
\text { preservation, gender equality and women access. } \\
\text { The total of final document can be review are } 25 \text {. }\end{array}$ & \\
\hline$\frac{\downarrow}{\text { Step } 3:}$ & \\
\hline $\begin{array}{l}\text { Reviewing documents by conducting analysis and } \\
\text { interpretation, making reports on the results of the } \\
\text { review and validation. }\end{array}$ & \\
\hline
\end{tabular}

(Source: Private document, 2020)

Fig. 2. The review stage process.

\section{Results and discussion}

Based on the results of the literature study conducted, elaborating the relationship between environmental preservation activities and aspects of gender equality is very important to support the achievement of urban sustainability. Women's involvement very important as agent of change and raising public awareness. They have approach to persuade and educate community to involve in preservation activity and reduce global warming. The women in urban area are taking part through advocacy, diplomacy, and campaign to help contribute the environmental preservation activities. Some of women being an agent of change or project 
leader, also people's representative are the best example of women participation in this kind of activities. In preservation with physical activity, women can do such physical tasks in supporting system divisions. Although the number of women who take part in physical activity in preservation are not many, but their concern in quality activities. In environmental preservation activities, women have contributed in the form of campaign activities and education on environmental protection, both to reduce waste and carry out recycling, use of ground water, prevent air pollution by greening the environment where they live and various activities to reduce the impact of global warming.

However, women's access to engage in natural resource preservation activities is still constrained by the cultural values of patriarchy. This causes discrimination and gaps in opportunities for access and preservation activities. Gender disparities on physical activities not only because of still communal with patriarchy value, but the men's empathy and perceptions on how women dealing with physical activities. In more patriarch community, men are feeling pity when seeing women dealing with physical job. Hence in that perception men are always helping women on physical job. Moreover, men often perceive certain physical activities are heavy or dangerous on women, including environmental preservation activities. Moreover, due to health considerations, women are prohibited to do some specific tasks in environmental preservation. From the previous researches and findings, the women contribute physically on environmental preservation through supporting tasks [21]. The contribution and involvement of women in environmental management in cities is related to the unique experiences of women in interacting with the urban environment [22]. The advocation and diplomatic activities made the women to be at the top of the project rather than man. Women are doing physical supporting and the manager while the men doing the clerical jobs beside of managing also. The women are more influential since they're on the top of this activities hence the consequence is the number of them are not many. Women more involve in non-physical preservation activity with focusing for education about preservation. Not much difference with advocation the advertisements also one of the most chosen way for women to help contribute in this activity. In advertisement, women often made the ideas and concepts and being the model themselves to tell the public of how they should begin to aware for their environmental well-beings.

The role of women in environmental protection and environmental awareness promotion activities is closely related to protecting ecosystems, natural resources and their management. Women can modify the planning in managing the environment at home and the environment where they live because management is related to the routine that women carry out in their daily activities at home. In fact, with regard to environmental hygiene, women have a very important role in the health of their families and strive to create a healthy and safe environment for them.

As in Figure 3, the application of gender equality in preservation activities in cities very important to note because the problem of environmental degradation continues to increase. This study focuses on women's involvement because as a marginalized group, women have rights and access to natural resources, and are involved in decision making. The problems of women to access and involve in preservation activities related with cultural, economic and political conditions shape the environmental management policies for the development of urban areas. The limitation for women access because of the condition in society still custom values applied, people's perception and mindset from male perspective, and the diversity in gender relations form [23]. The problem about gender disparities because of culture norm still patriarch must reduce with education and empowering women. Men and women have different types of contribution in urban environmental preservation. The sociological, historical and political factors take part in shaping the types of contribution made by women in urban environmental preservation. 


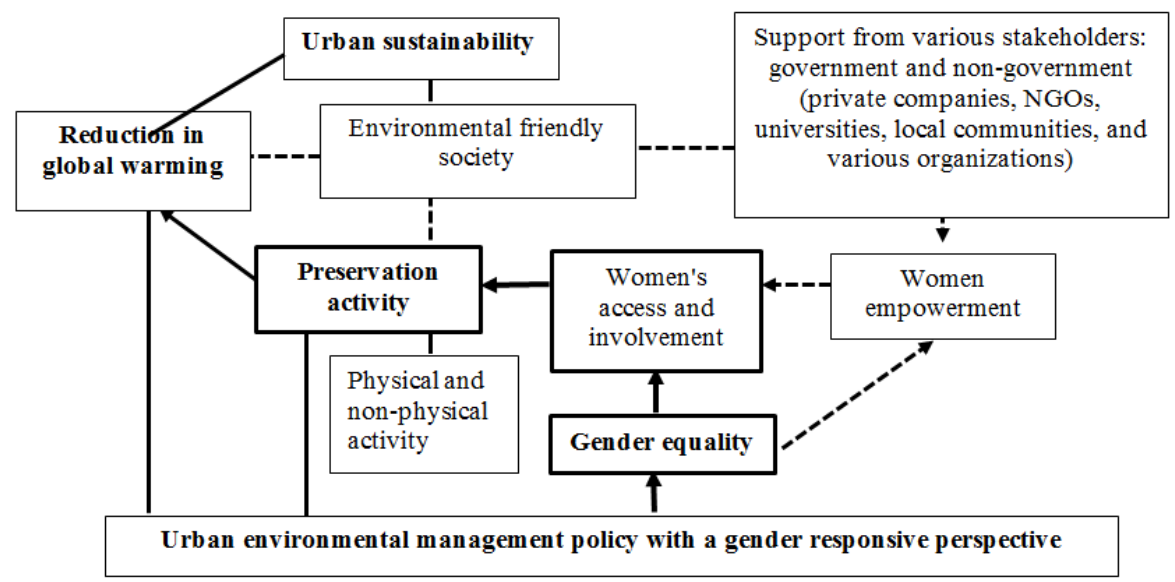

(Source: Research finding (private document), 2020)

Fig. 3. The linkages preservation activities with gender equality in environmental management.

The strategy of empowering women through education will improve women's abilities, knowledge and skills in utilizing technology for natural resource management, in addition to women having specific ways to manage the environment [24]. This condition need support from all stakeholders, include private companies, non-governmental organization or NGOs, college, and local communities. Because environmental preservation to reduce climate change effects in urban area must in collaboration and integrated activities. To develop environmental preservation policies with a gender equality approach, support from all parties is needed to raising women awareness and sensitivity at the community level on sustainability environmental and natural resource management. Besides, it is necessary to be sure that women are included in the community based environmental and natural resource management initiatives. Thus, identification of the role of women in environmental and natural resource management activities is very important, by also paying attention to the role of and the needs of women's groups related to providing access and involvement in environmental preservation activities.

\section{Conclusion}

This study shows that there is important relationship regarding environmental preservation with aspects of gender equality, regarding access and forms of involvement in activities. The human element needs to be linked in environmental preservation studies because humans are actors of environmental protection and preservation. So the involvement of women and men must be in equal portions and opportunities in all forms of preservation activities. The implication of this study is to provide alternative interventions in environmental management policies in urban areas with a gender perspective through access to natural resources and the involvement of women. Apart from that, this research also suggests evaluating environmental management policies that can encourage women's leadership to achieve a balanced development and support urban resilience. It will make open access for women to be involve in preservation activities more actively. 


\section{Acknowledgements}

This research was funded by the Higher Education Leading Basic Research Program (PDUPT) 2020 of the Ministry of Research and Technolog/National Research and Innovation Agency (Penelitian Dasar Unggulan Perguruan Tinggi (PDUPT) Kementerian Riset dan Teknologi/Badan Riset dan Inovasi Nasional/KEMENRISTEK/BRIN-Universitas Indonesia with contract numbers 8/E1/KP.PTNBH/2020 and 255/PKS/R/UI/2020.

\section{References}

1. A. Rome, Political Hemaphrodites: Gender and Environmental Reform in Progressive America, Oxford University Press (2006)

2. J. Begum, Women, Environment and Sustainable Development Making the Links, UNEP (2004)

3. S.M. Mirzaei, N. Jozeini, and O. Steel, Examining the social and cultural role in improving environmental quality J of Contemp Socio, 89, 14 (2009)

4. K.K. Zander, and S. Mathew, Estimating Economic Losses from Perceived Heat Stress in Urban Malaysia, Eco Eco 84-90 (2019)

5. N.B. Grimm, S.H. Faeth, N.E. Golubiewski, C.L. Redman, J. Wu, X. Bai, and J.M. Briggs, Global Change and the Ecology of Cities, Science, 319, 756-760 (2008)

6. K. Jax, D.N. Barton, K.M. Chan, R. Groot, U. Doyle, U. Eser, and S. Wichmann, Ecosystem Services and Ethics, Eco Econom, 93, 260-268 (2013)

7. J. Boyd, and S. Banzhaf, What are Ecosystem Services? The Need for Standardized Environmental Accounting Units, Eco Eco, 63, 616-626 (2007)

8. F.H. Besthorn, and D.P. McMillen, The Oppression of Women and Nature: Ecofeminism as a Framework for an Expanded Ecological Social Work Families in Society, The J of Contemporary Soc Service, 83, 221-232 (2002)

9. P. Potschin, and R. Haines-Young, Rio+10 Sustainability Science and Landscape Ecology, Landscape and Urban Planning, 75, 162-174 (2006)

10. C. Garrity-Bond, Ecofeminist Epistemlogy in Vandana Shiva's The Feminine Principle of Prakriti and Ivone Gebara's Trinitarian Cosmology, Feminist Theology, 26, 185-194 (2018)

11. UNEP, UN Women, PBSO and UNDP, Women and Natural Resources: Unlocking the Peacebuilding Potential (2013) https://wedocs.unep.org/

12. M. Schreurs, Women in Politics, Protecting the Environment in Northeast Asia, Cambridge University Press (2001)

13. S. Mann, Pioneers of US Ecofeminism and Environmental Justice, The Johns Hopkins University Press (2011)

14. M.A.A. Abdelali-Martini, Gender dimension in the conservation and sustainable, J of Socio-Eco, 37, 365-383 (2008)

15. B. Rahmani, and B. Majidi, Factors influencing the participation of women in an urban environment with an emphasis on attitude eco-feminist, Quarterly Geographical Journal, 2, 38 (2009)

16. S. Barr, Strategies for sustainability: citizens and responsible environmental behaviour, Area, 35, 227-240 (2003)

17. B. Agarwal, Does Women's Proportional Strength Affect their Participation? Governing Local Forests in South Asia, World Development, 38, 98-112 (2010)

18. T. Hanstad, Access to land improves women's lives around the world, The Seattle Times (2009) https://www.seattletimes.com/

19. K. Seers, Qualitative systematic reviews: their importance for our understanding of 
research relevant to pain, British J of Pain, 9, 36-40 (2015)

20. K. Hannes, and K. Macaitis, A move to more systematic and transparent approaches in qualitative evidence synthesis: update on a review of published papers, Qual Res, 122 ,402-442 (2012)

21. F. Steady, Climate Change and Liberation in Africa, Jean Ait Belkhir, Race, Gender \& Class Journal, 312-333 (2014)

22. D. Asteria, H. Herdiansyah, and I.W.A. Apriana, Women's Environmental Literacy as Social Capital In Environmental Management For Environmental Security of Urban Area, IOP Conf. Ser: Earth and Environ Sci, 30, 1-6 (2016)

23. D. Asteria, Budidarmono, H. Herdiansyah, and N.L. Ni'mah, Gender sensitive education in watershed management to support environmental friendly city, IOP Conf. Ser.: Earth Environ. Sci, 126, 012146 (2018)

24. P.B. Cobbinah, M.O, Erdiaw-Kwasie, and P. Amoateng, Rethinking Sustainable Development within the Framework of Poverty and Urbanisation in Developing Countries, Environ Dev, 13, 18-32 (2015) 